Portland State University

PDXScholar

\title{
A Woman Named Fulvia: Life, Actions, and Perceptions
}

Jeneveve T. Winchell

Portland State University

Follow this and additional works at: https://pdxscholar.library.pdx.edu/honorstheses

\section{Let us know how access to this document benefits you.}

\section{Recommended Citation}

Winchell, Jeneveve T., "A Woman Named Fulvia: Life, Actions, and Perceptions" (2018). University Honors Theses. Paper 620.

https://doi.org/10.15760/honors.632

This Thesis is brought to you for free and open access. It has been accepted for inclusion in University Honors Theses by an authorized administrator of PDXScholar. Please contact us if we can make this document more accessible: pdxscholar@pdx.edu. 


\section{THESIS APPROVAL}

The thesis of Jeneveve Winchell for the Bachelor of Arts with Honors in History was presented June 7th, 2018, and accepted by the thesis committee and the department.

Dr. Brian Turner, Advisor

Dr. John Ott, Reader

DEPARTMENT APPROVAL:

Dr. Tim Garrison, Chair

History 


\section{A WOMAN NAMED FULVIA: LIFE, ACTIONS, AND PERCEPTIONS}

by

JENEVEVE WINCHELL

A thesis submitted in partial fulfillment of the requirements for the degree of

\section{BACHELOR OF ARTS WITH HONORS}

in

HISTORY

Portland State University

2018 


\section{Table of Contents}

INTRODUCTION $\ldots \ldots \ldots \ldots \ldots \ldots \ldots \ldots \ldots$

CHAPTER ONE. Fulvia, the Daughter ............ 5

CHAPTER TWO. Fulvia, the Wife and Mother ...... 15

CHAPTER THREE. Fulvia, the Politician .......... 22

CHAPTER FOUR. Fulvia, the General. . . . . . . . . 28

CONCLUSION ........................ 44

Bibliography ........................ 45 
In the midst of the chaos of the Late Roman Republic, as senators plotted conspiracies, a general became dictator perpetuo, and civil wars raged, a woman named Fulvia rose to unprecedented political power. Described by Plutarch as "a woman who took no thought for spinning or housekeeping, nor would she deign to bear sway over a man of private station, but [who] wished to rule a ruler and command a commander," Fulvia demonstrated political ambition from our earliest records of her life. ${ }^{1}$ The wife of three prominent politicians, Fulvia has survived in the historical record as an unprecedented Roman matron. Yet what we know of this anomalous woman has been passed down to us from ancient sources that relied upon the opinions of her opponents. Modern scholars are left to sort out a picture of her life and contribution to the Late Roman Republic.

Treatments by ancient scholars like Plutarch, Cicero, Appian, and others vilify or minimize Fulvia. They accuse her of being violent, cruel, and immoral. ${ }^{2}$ More recent works often fall into the traps of accepting without question the veracity of heavily biased ancient sources and view Fulvia as little more than a meddling wife of powerful men, or if they strive for a new perspective, examine the intersection of Fulvia's roles as a wife and political figure. ${ }^{3}$ Yet both of these portraits are over-simplified and under-developed.

\footnotetext{
${ }^{1}$ Plut. Ant. 10.3.

${ }^{2}$ Cic. Phil 2.48, 2.95.

${ }^{3}$ Charles L. Babcock, "The Early Career of Fulvia," AJPh 86, no. 1 (1965); Richard A. Bauman, Women and Politics in Ancient Rome (London: Taylor and Francis, 1994); Corey T. Brennan, "Perceptions of Women's Power in the Late Republic," A Companion to Women in the Ancient World, 2012; Diana Delia, "Fulvia Reconsidered," in Women's History and Ancient History, ed. Sarah B. Pomeroy (Chapel Hill: University of North Carolina Press, 1991); W. Jeffrey Tatum, The Patrician Tribune: Publius Clodius Pulcher (Chapel Hill: University of North Carolina Press, 2017); Kathryn E. Welch, "Antony, Fulvia, and the Ghost of Clodius in 47 B.C." Greece \& Rome 42, no. 2 (1995): 182-201.
} 
How each secondary work falls into these categories depends on the route by which they arrive at their understanding of Fulvia. The works focused on one or more of her husbands tend to limit Fulvia to the role of a willful, and often troublesome, wife. These are also the pieces of scholarship that accept the assessments of the ancient sources without question. ${ }^{4}$ The works which question the ancient scholars and attempt to re-examine Fulvia's political influence take steps in the right direction, but fall short by only analyzing her in one, or at most two, of her roles. ${ }^{5}$ Usually, these scholars concern themselves with the intersection between wife and politician - in other words, how Fulvia manipulated politics in the service of her husbands. ${ }^{6}$ In search of a less biased understanding of Fulvia's life, motives, and actions, I examine her life through a new lens. In his 2003 book, Nero, Edward Champlin reexamined the life of the infamous Roman emperor. By separating Nero's actions from the expectations and reactions of his contemporaries, Champlin challenged the intentions given to the emperor by ancient scholars. He focuses on potential motives for Nero's actions and how those may have benefitted the emperor. These are compared to the motives given to Nero by his peers or later scholars. Champlin writes, "for most of Nero's actions, even the most notorious... we can find a purpose which may have nothing to do with the motives ascribed to him." ${ }^{.7}$ This methodology provides an

\footnotetext{
${ }^{4}$ Arthur Weigall, The Life and Times of Marc Antony (New York: G.P. Putnam's Sons, 1931); J. P. V. D. Balsdon, Roman Women: Their History and Habits (London: Bodley Head, 1962).

${ }^{5}$ Though a fascinating historical character, no full biography of Fulvia exists. Outside of limited scholarly interest in her political career, she is most frequently found in the biographies of two of her husbands, Clodius and Mark Antony. Two masters' theses are the closest approximations of full biographies on Fulvia: "The cultural creation of Fulvia Flacca Bambula" by Erin Leigh Wotring (2017) and "A Study of Fulvia" by Allison Weir (2007).

${ }^{6}$ Babcock, "The Early Career of Fulvia"; Bauman, Women and Politics in Ancient Rome; Brennan, "Perceptions of Women's Power"; Delia, "Fulvia Reconsidered"; Tatum, The Patrician Tribune; Welch, "Antony, Fulvia, and the Ghost of Clodius,"; Judith P. Hallett, "Fulvia, mother of Iullus Antonius: New approaches to the sources on Julia's adultery at Rome," Helios 33, no. 2 (2006), 149-51 similarly only examines Fulvia in two of her many roles, however she discusses Fulvia as a mother and how that interacted with her role as a military leader during the Perusine War.

${ }^{7}$ Edward Champlin, Nero (Cambridge: Harvard University Press, 2003), 237.
} 
opportunity to reexamine old evidence, and to locate new insight in the form of fresh perspectives on ancient motives.

Reevaluating what we know about Fulvia's life and actions requires sorting through longstanding but unfounded assumptions and ancient biases. However, clearing this slate offers us the opportunity to employ a lens similar to the one devised by Champlin for his analysis of Nero - one which examines what actions we know Fulvia took, questions what might have motivated such actions, and discusses how these actions could have benefitted her. Through this method of analysis we can better understand Fulvia as a multifaceted historical figure.

In order to achieve this understanding, and in following, Champlin's methodology, this study requires an assumption of rationality. Therefore, if we assume Fulvia was rational what purposes prompted her actions besides those motives assigned to her by our sources? Why did she do the things she did, and how did they benefit her? As Champlin writes of the Emperor Nero, "He constantly calculated the effects of his actions on an audience." ${ }^{\prime 8}$ I believe the same is true for Fulvia.

This is not an attempt, however, to argue that logic and rational decision making spurred all of Fulvia's actions. Though our sources, especially the ancient sources, paint Fulvia as a cold, calculating, and unfeeling figure, there are as many instances in which love may have motivated her actions as there are displays of ambition or vindictiveness. Ultimately, Fulvia was human. To believe that she never acted irrationally or illogically, whether influenced by strong emotions or not, is inherently flawed. To this end, we also have to acknowledge that rationality is subjective, and such concepts can differ both culturally and from person to person. That which we may consider logical today may not match what may have been rational in Fulvia's mind or in her

${ }^{8}$ Champlin, Nero, 237. 
time. This is the flaw in Champlin's methodology. No one acts solely according to rational decision-making, largely because "rational" is far too subjective and abstract to be defined.

In this study I discuss Fulvia in four, mostly chronological, stages of her life. I separate her, quite intentionally, into her roles as a daughter, wife and mother, politician, and eventually a military leader. Categorizing our subject in this manner highlights the typical way in which modern scholars treat Fulvia, as a one-dimensional caricature, and demonstrates that such limited and shallow assessments are flawed. This organizational irony, if you will, shall be utilized to prove Fulvia was never simply a wife or mother or politician or general. At various points in her life, she expressed and acted in relation to many or all of these roles and their unique responsibilities simultaneously. This multiplicity of motive and role will be demonstrated in each section by noting the times and events when Fulvia's roles overlapped, in many cases potentially influencing her decisions and actions. The goal of this work is both to challenge various methodologies of studying ancient figures (i.e., Champlin's lens, the limited methods of Fulvia's modern scholars, and the biased approaches of the ancient sources) and to illuminate a richer, more nuanced portrait of the oft-maligned or ignored Fulvia. 


\section{Fulvia, the Daughter}

When it comes to Fulvia's childhood, there is much we do not know. In this section, I discuss the biographical information we can discern and analyze what estimations we can safely make about the gaps in our records. Then follows an overview of the average childhood and upbringing of a girl of Fulvia's class to help us understand what our subject's youth may have been like, as well as offering insight into how Fulvia's interest in politics may have sprouted.

Until Fulvia appears in 52 BCE as the wife of Publius Clodius Pulcher and mother of their daughter, Clodia, record of her life does not exist. ${ }^{9}$ Even her birth year remains a mystery, with estimates ranging from $84 \mathrm{BCE}$ to $70 \mathrm{BCE} .{ }^{10}$ Babcock bases his date of $84 \mathrm{BCE}$ on a complex analysis of political events and the marriages of her mother, Sempronia. However, this conservative date places Fulvia as thirty-seven or thirty-eight at the time of her marriage to Antony; and thirty-nine when she gave birth to her youngest child, Iullus Antonius. While this is not an impossible scenario, it seems likely that she was born later than Babcock's estimation. ${ }^{11}$ On the other end of the spectrum, however, $70 \mathrm{BCE}$ is an even more absurd date of birth. Cicero implies that Fulvia had an affair with Antony in 58 BCE, while married to Clodius. ${ }^{12}$ If Fulvia had been born in $70 \mathrm{BCE}$, she would have been twelve when this occurred. $58 \mathrm{BCE}$ also happens to be the latest possible year for the marriage of Fulvia to Clodius, with some estimations placing the union as early as 62 BCE. ${ }^{13}$ Wealthy Roman daughters typically married in their early teen

\footnotetext{
9 The name of Fulvia and Clodius' daughter is recorded in our sources as both Clodia and Claudia. For ease of writing, I shall refer to her exclusively as Clodia as this spelling is closest to that of her father's name.

${ }^{10}$ Babcock, "The Early Career of Fulvia," 7-8; AllisonWeir, “A Study of Fulvia,” (MA Thesis, Queen’s University, 2007), 3.

${ }^{11}$ Bruce W. Frier, "Natural Fertility and Family Limitation in Roman Marriage," Classical Philology 89, no. 4 (1994): 321. In this work, Frier addresses female fertility in relation to age. He observes the natural decline of female fertility over time, culminating in a drastic drop in fertility occurring on average in a woman's late 30's or early 40’s.

${ }^{12}$ Cic Phil. 2.48.

${ }^{13}$ Babcock, "The Early Career of Fulvia," 7.
} 
years, ${ }^{14}$ and it is reasonable to argue that this held true for Fulvia. Using the median of potential matrimonial dates, $60 \mathrm{BCE}$, provides a more moderate guess at Fulvia's date of birth, somewhere around $75 \mathrm{BCE}$. I would be reluctant to place her birth earlier than $80 \mathrm{BCE}$ or later than $72 \mathrm{BCE}$ due to the dates we do know such as the births of her children. ${ }^{15}$

Whatever her birthday, it is reasonably clear that Fulvia was born in Tusculum, in her family's home. Her family consisted of wealthy plebeians, many of whom had the honor of holding a consulship or other political offices in their lives. However, Fulvia's father, Marcus Fulvius Bambalio, was a man of "no rank" who was ridiculed for a speech impairment, likely a lisp according to the derisive suffix "Bambalio." ${ }^{16}$ His direct connection to the long line of prominent Fulvian politicians is unclear, however scholars believe him to be the last male to bear the family name. ${ }^{17}$

There survives little record offering us a glimpse into what kind of relationship Fulvia had with her father. He is thought to have died around the year $70 \mathrm{BCE}$, which, depending on where one places Fulvia's birth year, would have her between the ages of two and ten when he passed. Fulvia would have certainly been young, and if she had a close relationship with her father, his passing may have been traumatic. Contrary to this narrative, at least one of our sources offhandedly notes that Sempronia may have divorced Bambalio - suggesting that divorce, not death, freed Fulvia's mother for remarriage. This source suggests that Fulvia had a continued relationship with her father at least until her third marriage, because "Antony is said to [have been] fond of Bambalio." 18 The nature of a potential ongoing relationship with her father is

\footnotetext{
${ }^{14}$ Sarah B. Pomeroy, Goddesses, Whores, Wives, and Slaves (New York: Schocken Books, 1995), 164.

${ }^{15}$ Clodia was born in 56/57 BCE, Marcus Antonius Antyllus was born in $47 \mathrm{BCE}$, and Iullus Antonius was born in 45 BCE.

${ }^{16}$ Cic. Phil 2.36, 3.16; Dio 55. 47.4

${ }^{17}$ Babcock, "The Early Career of Fulvia," 4; Bauman, Women and Politics in Ancient Rome, 83.

${ }^{18}$ Cic in Dio 45.47.4, Babcock, "The Early Career of Fulvia," 8.
} 
unclear, though Antony's affection for Bambalio could support the idea that he lived into his daughter's adulthood, or that he knew and had a relationship with Antony before his marriage to Fulvia.

However, even if Fulvia had little to no relationship with her father, or perhaps even a bad relationship with him, it serves us to question how her father's reputation may have influenced her, even after his death, whenever that may have been. Fulvia bore her father's name, and due to her father's status as the last male of his line and her position as his only child, she was the last to carry the Fulvian family name. Understanding this, we can see how Fulvia may have felt a sense of obligation to honor or even redeem her family's name. In these ways familial honor could have contributed to her later political ambitions. ${ }^{19}$ The forces of familial obligation and honor are logical influences on Fulvia's life and decision-making. Roman men certainly felt these pressures, though whether their sisters bore the weight of such responsibilities as well is less certain. ${ }^{20}$ However, the importance of family legacy among the elite in the Roman Republic supports the theory that Fulvia, as the only child of the last Fulvii, may have been moved by these sentiments.

Fulvia's mother was Sempronia, the daughter of an eccentric rich man known best for dressing in theatre costume and throwing money to people in the forum. ${ }^{21}$ Fulvia's maternal great-grandfather, however, was the prominent politician and consul in the year 129 BCE, Gaius Sempronius Tuditanus. This Tuditanus also authored one of the early works on public law in Rome. ${ }^{22}$ As the daughter and only known child of the wealthy politician Tuditanus' only male

\footnotetext{
${ }^{19}$ Catherine Baroin, "Remembering One's Ancestors, Following in their Footsteps, Being Like Them: The Role and Forms of Family Memory in the Building of Identity," in Children, Memory, and Family Identity in Roman Culture, eds. Véronique Dasen and Thomas Späth (Oxford: Oxford University Press, 2010), 19-48.

${ }^{20}$ Baroin, "Remembering One's Ancestors," 19-21.

${ }^{21}$ Bauman, Women and Politics in Ancient Rome, 83; Cic. Phil. 3.16; Babcock, "The Early Career of Fulvia," 3-5.

${ }^{22}$ Bauman, Women and Politics in Ancient Rome, 83.
} 
heir, Sempronia likely inherited considerable wealth. ${ }^{23}$ As the last of the Fulvii and likely the heir of some of her mother's family money, ancient and modern scholars alike agree that Fulvia possessed considerable economic resources. ${ }^{24}$ This wealth will be relevant later in the discussion of Fulvia's marriages.

Marriage in the context of Fulvia's childhood requires discussion due to Sempronia's unions, both preceding and following her marriage to Fulvia's father, Marcus Fulvius Bambalio. Sempronia's first marriage joined her with Pinarius Natta, with whom she had a son, L. Pinarius Natta. ${ }^{25}$ Her next union bound her to Bambalio, Fulvia's father. Sempronia's third marriage allied her with Lucius Licinius Murena, consul in the year 62 BCE. Records do not show Sempronia and Murena bearing any children together, however the union of Fulvia's mother and this prominent politician remains important. Not only did this marriage unite several key political figures of the era, including Murena, Clodius, Natta, and Julius Caesar, ${ }^{26}$ it also may have

\footnotetext{
${ }^{23}$ The inheritances of both Sempronia and Fulvia are complicated by the Lex Voconia, a piece of Roman legislature put into place in 169 BCE. The Lex Voconia prohibited men and women of significant wealth from making a woman their sole heir. This law was intended to prevent women from inheriting large fortunes. This suggests, as Hallet points out, that Roman lawmakers recognized that elite women who possessed significant wealth could be a threat to the "Roman patriarchal social structure." (Hallett, 1984, 92-93) A Roman could circumvent this legislation by not participating in the census, if he was a man, subsequently forfeiting certain civil rights or by putting money into a trust (fideicommissum) that could then be transferred to a female heir. Julie Dodds, "The Impact of the Roman Law of Succession and Marriage on Women's Property and Independence," Melbourne University Law Review 18 (1992). The Lex Voconia may or may not have impacted their inheritances, and unfortunately our ancient sources over no clarification on how either woman inherited her wealth. All we can speculate is that if either or both inherited under the Lex Voconia, they could have only received, at most half, of their families' estates. This could speak to the affluence of the Sempronii and Fulvii lines, though due to the ancient scholars references to Fulvia's monetary resources, I find it most likely that Bambalio's money, if not both estates evaded the Lex Voconia.

${ }^{24}$ Cic Phil, 3.16; Babcock, "The Early Career of Fulvia," 5. It should be noted that if Fulvia's father did not die in her youth, this inheritance would not have served as an instantaneous incentive for marriage to Fulvia, as she would have only possessed a dowry to offer to potential spouses. However, it is possible that one or more of her spouses considered the wealth she stood to gain once her father passed when they agreed to marry her.

${ }^{25}$ Jerome S. Arkenberg, "Licinii Murenae, Terentii Varrones, and Varrones Murenae: A Prosopographical Study of Three Roman Families," Historia: Zeitschrift für Alte Geschichte 42, no. 3 (1993): 343. L. Pinarius Natta, Fulvia's older half brother, would later be elected pontifex in 58 BCE thanks to the influence of Clodius, his brother-in-law. Natta's marriage to Julia, Caesar's sister, would connect Fulvia and Julia as sisters-in-law and give Fulvia ties to Julius Caesar.

${ }^{26}$ The complex web of marriages and adoptions which facilitated these alliances deserves a much more thorough examination than I am able to offer here. See Arkenberg, "Licinii Murenae," 326-51, for a detailed analysis of these relationships.
} 
bestowed Fulvia with more political legitimacy in the context of her family. Since neither her father nor her maternal grandfather held any political offices, a lineage of successful politicians even if only related by marriage - may have aided Fulvia in securing advantageous spouses later in her life by offering political allies to her future husband(s). ${ }^{27}$

Fulvia's relationship with her stepfather deserves attention since as a politician and consul, Murena undoubtedly socialized with a variety of prominent Romans, and it seems reasonable to assume that Sempronia's marriage to her third husband expanded Fulvia's social circle and possibly introduced her to Roman politicians. At various points in his career, Murena benefitted from close associations with Cicero, Clodius, Aulus Terentius Varro, ${ }^{28}$ Quintus Hortensius Hortalus, ${ }^{29}$ and others. ${ }^{30}$ We have little or no way of knowing what impact Murena had on Fulvia, or if he played a role in inspiring her political ambitions - however, such a potential relationship cannot be dismissed outright either. At the very least, he may have offered her insight about, or connections to, the political landscape of the day.

Fulvia's mother, Sempronia, seems as likely to have educated her daughter on political maneuverings as Fulvia's stepfather. Cicero suggests that both Fulvia and Sempronia had a hand in helping Clodius get L. Pinarius Natta elected pontifex in 58 BCE. About this event Cicero says, "He [a voter] only was present, if indeed he was present, whom you yourself instigated, whom his sister entreated, and whom his mother compelled to be so." ${ }^{31}$ Arguing that Clodius manipulated the vote by stacking the assembly with his own supporters, with the help of his wife

\footnotetext{
27 Arkenberg, "Licinii Murenae," 344.

${ }^{28}$ Varro was a lieutenant under Murena and a politician. Broughton, The Magistrates of the Roman Republic (American Philological Association, 1952), 70.

${ }^{29}$ Hortensius was a lawyer, orator, and politician. Before retiring in $61 \mathrm{BCE}$, Hortensius was often an ally of Cicero. "Hortensius Hortalus, Quintus." in The Oxford Classical Dictionary (Oxford: Oxford University Press, 2012).

${ }^{30}$ Arkenberg, "Licinii Murenae," 344; Babcock, "The Early Career of Fulvia," 6.

${ }^{31}$ Cic. Dom. 118.
} 
and mother-in-law, Cicero gives credit to Fulvia and Sempronia for influencing politics.

Sempronia also remarried in advantageous ways, ${ }^{32}$ a strategy that Fulvia would later adopt in her own marriages. For these reasons, and Sempronia's continued presence during political moments in Fulvia's life, ${ }^{33}$ it seems plausible that Fulvia learned some of her political navigation from her mother. Though we have no record of Sempronia breaking as many norms as her daughter later disregarded, we can certainly recognize the similar patterns in their behavior. Logically, we can conclude that if Sempronia did teach Fulvia anything about politics, it was likely how to influence and shape such affairs as a woman.

Fulvia's childhood may have been drastically different from the norm, but since we have no records of her or her life until early adulthood, our best chance at understanding her youth lies with the average experience of a girl of the same class. Births, especially among the wealthy who had the means and time, were social occasions. They usually occurred at the house of the expectant mother's husband or his family. Men, whether relatives, doctors, or even the father of the unborn child, were rarely present for the actual birth, though they participated in important ceremonies and rituals after the child was born. Women, usually female relatives from both sides of the family and a midwife, attended the mother as she endured labor and gave birth. Midwives were essential in this process and were hired by any family who could afford one. ${ }^{34}$

After the baby was born, the father, or the patriarch of the father's family if he was still living, decided whether the child was healthy enough to be kept and reared. If a newborn was

\footnotetext{
32 As discussed above, Marcus Fulvius Bambalio likely possessed significant wealth as the last male of his family line, while L. Licinius Murena the offered social connections of a rising politician.

${ }^{33}$ I am alluding to Sempronia's presence at the trial of Milo and at Fulvia's grief-stricken eulogy which stirred the attending crowd into a riot. Both of these events I discuss in further detail later, highlighting how Fulvia could simultaneously be a wife, daughter, and politician.

${ }^{34}$ Beryl Rawson, "The Roman Family," in The Family in Ancient Rome: New Perspectives, ed. Beryl Rawson (New York: Cornell University Press, 1986), 13.
} 
sickly or deformed, they would likely be killed or abandoned. ${ }^{35}$ If the father or patriarch agreed to rear the child, he would raise the baby into the air, a symbolic gesture that also carried legal obligations. Once they were accepted in this way, the father had legal responsibilities to provide and care for the child. ${ }^{36}$

Following the birth would be many religious ceremonies and rituals, often accompanied by celebrations if the family could afford it. Wet nurses were hired to care for infants and were an important part of Roman children's development, despite the common opinion that it was healthier for mothers to breastfeed their own children. ${ }^{37}$ Wet nurses were also used by a diverse range of families on the socio-economic scale, though they were a staple of wealthy households like the one in which Fulvia was raised. ${ }^{38}$

As children of the upper classes grew, they would interact with a variety of adults. Nurses, tutors, slaves, their parents, relatives, and friends of the family were prominent in their lives. Female relatives were more likely to have frequent, informal contact with the children, while their male counterparts were more likely to interact with them in more formal situations. Children attended festivals and other social occasions, such as weddings, funerals, public ceremonies, games, and religious gatherings where they met new people and mingled with those they knew. They also met and interacted with fellow children at these events. ${ }^{39}$

Educations started early for wealthy Roman children ${ }^{40}$ At home children were accompanied nearly at all times by adults, either nurses, tutors, slaves, parents, or relatives, who

\footnotetext{
${ }^{35}$ Rawson, "The Roman Family," 12.

${ }^{36}$ Rawson, "The Roman Family," 13-4; Pomeroy, Goddesses, Whores, Wives, and Slaves, 164-5.

${ }^{37}$ Rawson, "The Roman Family," 14-5.

38 Rawson, "The Roman Family," 15.

${ }^{39}$ Rawson, "The Roman Family," 17-8.

${ }^{40}$ Rawson, "The Roman Family," 20; Lauren Caldwell, Roman Girlhood and the Fashioning of Femininity (Cambridge: Cambridge University Press, 2014), 18.
} 
could mentor and educate them on the fundamental lessons of childhood. ${ }^{41}$ Exact ages of formal schooling for both girls and boys varied, however most children began coed classes around four or five years old. In school they often studied Latin, Greek, and literature. After an average of six or seven years of schooling alongside their male counterparts, girls were typically removed from classrooms and resumed at-home tutoring. Parents took this step to protect their daughters' modesty. ${ }^{42}$

Education was important for wealthy Roman daughters, and it continued into their adolescence. One reason for educating girls was to prepare them for their role as mothers, who took an active part of their children's educations, the common thought being that highly educated women raised better educated sons. ${ }^{43}$ Marriage and having children of one's own stood as a common goal among elite parents for their children. The minimum marrying age was twelve for Roman girls and fourteen for boys, however both groups typically did not marry until older than these legal minimums. While girls of the lower classes married in their late teens and early twenties, wealthy daughters were more likely to be married in their early teens. These were almost exclusively arranged marriages, organized by the bride's male kin or a chosen guardian. ${ }^{44}$ While the sons of elite Roman families only possessed legal guardians until the age of fourteen, their sisters had guardians in perpetuity. Women retained their guardians during and after marriage, resulting in women being subject to their husbands' authority after that of their father, then back under their fathers' authority in the event of divorce or death. ${ }^{45}$ Legally, Roman

\footnotetext{
${ }^{41}$ Rawson, "The Roman Family," 18.

42 Rawson, "The Roman Family," 20; Caldwell, Roman Girlhood, 18; William Anton Smith, Ancient Education (New York: Philosophical Library, 1955), 189.

${ }^{43}$ Rawson, "The Roman Family," 40-1.

${ }^{44}$ Pomeroy, Goddesses, Whores, Wives, and Slaves, 164. Rawson, "The Roman Family," 27. Sons also married later in their lives, with ages ranging from mid-twenties to early thirties.

45 Rawson, "The Roman Family," 25.
} 
women required guardian approval before selling land, making contracts, testifying, and other private and public transactions. However, by the Late Republic the authority of guardians over Roman matrons had dwindled in practice, if not in law. This can be noted in the autonomous financial and social actions of women such as Cornelia, Mother of the Grachii; Terentia, the wife of Cicero; and our own Fulvia.

It would be highly unrealistic to believe that the woman who incited a riot that resulted in the destruction of the building that housed the Senate ${ }^{46}$ could be governed by anyone. ${ }^{47}$ However, this does raise questions as to who functioned as Fulvia's guardian, even if this role served as primarily advisory. As an extant copy of Bambalio's will eludes us, ${ }^{48}$ it is difficult to ascertain who inherited the burden of responsibility over Fulvia. ${ }^{49}$ However, knowing this mysterious guardian and his influence, or lack thereof, on Fulvia could help us understand how radical Fulvia's life and actions were in the context of her time. The difference between a guardian who cared little about Fulvia's affairs and only offered aid or advice when it was sought out is very different than that of guardian whom Fulvia regularly disobeyed or disregarded. Additionally, her guardian may have played an active role in her life during her periods of widowhood, but happened to agree with and approve all of her decisions.

\footnotetext{
${ }^{46}$ In 52 BCE, in the aftermath of Clodius' murder, Fulvia gave a eulogy to a crowd in Rome. In response to Fulvia's grief-stricken speech, the crowd turned into an aggressive mob which carried Clodius' body to the steps of the Senate house, and while attempting to cremate him on the steps, managed to burn the building down. This event will be discussed in more detail later in the paper.

${ }^{47}$ This is not to suggest that Fulvia acted against the guidance of her appointed guardian. I simply find it difficult to imagine Fulvia, the woman with the support of Clodius' collegia, marrying someone that she did not want to marry or someone she did not view as advantageous to her. This is simply a suggestion that Fulvia likely played an active role in choosing her second and third husbands, managing her finances, and building the alliances that would later initiate her political maneuverings.

${ }^{48}$ As does the knowledge of when specifically Bambalio died. The significance of this being that if Bambalio survived into Fulvia's third marriage, he would have served as her guardian after the deaths of her first two husbands.

${ }^{49}$ Pomeroy points out that by the Late Republic, guardianship over elite Roman matrons was a larger burden for the guardian than it was a hindrance for their wards (Pomeroy, Goddesses, Whores, Wives, and Slaves, 151). I would suspect that this was especially true for Fulvia's guardian, who at minimum had to contend with her inciting a riot and testifying publicly after the death of her first husband.
} 
Fulvia's youth and her role as a daughter suffers from a complete shortage of source material; however, the questions of her inheritance, familial relationships, and the origins of her political ambitions are essential to our understanding of Fulvia in her complex roles as she enters our extant records. Her economic resources played into her marriages, including how desirable a wife she would be and how she might be able to assist a spouse's aspirations. Her relationships with her mother, stepfather, and father, if he was alive, could have impacted Fulvia's political relationships and loyalties. None of these roles stands alone, and the intricacies of Fulvia's life and decisions lies tied up inside of them all. 


\section{Fulvia, the Wife and Mother}

Fulvia's first husband was Publius Clodius Pulcher. Murdered in 52 BCE, Clodius' death preceded and precipitated Fulvia's first appearance in our ancient records. In this section, I analyze what factors may have influenced her choices in marriage, including her choices of spouses. Then I examine how the ancient sources claim or imply Fulvia failed as a wife and mother, and whether those assessments are fair. Throughout, her political actions and influences are highlighted to demonstrate again that Fulvia's roles overlapped at every turn.

Clodius, and his political rival, Titus Annius Milo, met on the Via Appia outside of Rome on 18 January 52 BCE. During the ensuing skirmish, Milo’s companions ended up killing Clodius. ${ }^{50}$ Shortly after this event, Fulvia had her dead husband's body brought out onto the street in Rome. Then she gave a eulogy that turned the assembled crowd riotous. That mob took Clodius' body, carried it to the steps of the building which housed the Roman Senate, and while cremating the popular politician's body on the building's front steps, burned the structure to the ground. ${ }^{51}$ This should be recognized as the exquisitely unconventional first impression that it is. A short while later, Fulvia and her mother Sempronia appeared at the trial of her husband's murderer.

Though likely a symptom of our limited sources, this anecdote certainly gives the impression that Fulvia knew how to make an entrance, so to speak. Fulvia married Clodius sometime between $62 \mathrm{BCE}$ and $58 \mathrm{BCE}$, likely in her late teen years. Clodius came from a

\footnotetext{
${ }^{50}$ App 2.21.

${ }^{51}$ Brennan, “Perceptions of Women's Power," 357.
} 
distinguished family of politicians, and he served on the staff of Murena, Fulvia's future stepfather, in Gaul. Fulvia's marriage to the rising politician was politically advantageous for both her step-father and her new husband. ${ }^{52}$ Elite Roman marriages were almost always politically motivated, demonstrating to us once more how Fulvia's roles overlapped and intertwined. After Clodius' murder at the hands of Milo, she married Gaius Scribonius Curio. Curio was a good friend of Marcus Tullius Cicero, the man who had defended Milo at his aforementioned trial. ${ }^{53}$ As politically ambitious as Clodius, and despite being from a less prominent family, Curio offered considerable wealth in marriage.$^{54}$ In turn, Fulvia offered political alliances and possibly most importantly, access to and the support of Clodius' collegia ${ }^{55}$ Clodius' collegia were his clubs, or gangs, of political supporters, which he utilized to influence public votes, intimidate opponents, and even commit the occasional crime. ${ }^{56}$ In addition to her wealth, these assets, especially Clodius' collegia, made Fulvia one of the most sought-after widows in Rome. Whether she was aware that she had so much power, though, is uncertain. She may have purposefully cultivated and held on to the respect of her late husband's collegia so she could use their support to her advantage, or the continued loyalty may have been a happy accident. If Fulvia did carefully coordinate Clodius' collegia to fall under her control after his death, such movements could be viewed as the early acts of a clever political actor. Intentional management of the collegia would also suggest that Fulvia was aware of her burgeoning power, or at least the

\footnotetext{
52 This might suggest that Murena and/or Sempronia had a hand, if not major control, over the arrangement rather than Bambalio (if he was alive) or another outside guardian of Fulvia.

${ }^{53}$ Babcock, "The Early Career of Fulvia," 6.

${ }^{54}$ Babcock, "The Early Career of Fulvia," 9-10.

${ }^{55}$ Babcock, "The Early Career of Fulvia," 9. A collegium is defined as "any private association of fixed membership and constitution" according to the OCD. "collegium." in The Oxford Classical Dictionary (Oxford: Oxford University Press, 2012).

${ }^{56}$ Richard A. Billows, Julius Caesar: The Colossus of Rome, 167-8; Tatum, The Patrician Tribune, 235-8.
} 
power that controlling such groups could offer her, both in selecting an advantageous spouse and in the influencing of politics.

Marriage to Antony - her third husband - also offered significant political potential, ${ }^{57}$ particularly in his closeness with Julius Caesar. Indeed, Julius Caesar supposedly ordered Antony to get married again in an attempt to curb the younger man's drinking, gambling, and affairs with various women. ${ }^{58}$ Our sources are unclear, but since Caesar likely knew Fulvia from their family ties and the political alliances of her former husbands, ${ }^{59}$ it seems important to consider whether Julius Caesar told Antony to marry anyone, or whether he told his protege to marry Fulvia specifically? Antony had plenty of reasons to marry Fulvia. Her wealth and control over Clodius' followers remained specifically enticing, ${ }^{60}$ but did Caesar recognize this? If Caesar recommended marriage to Fulvia particularly, it is possible that he did so in recognition that Fulvia was a woman of strong will. Perhaps he supported the marriage under the belief that a strong spouse would be exactly what Antony needed to get him on the right track once more. Caesar might have also hoped to connect himself to Clodius' supporters by encouraging the marriage of his close ally, Antony, to Fulvia, Clodius' widow. If either or both of these scenarios influenced Caesar's support of the marriage, they would highlight that Fulvia's reputation as a

\footnotetext{
${ }^{57}$ All three of Fulvia's husbands had connections with the others. Antony briefly allied himself with Clodius in 58 BCE. At the time Curio and Antony enjoyed a close friendship, Curio led a group opposing legislation that would harm Clodius in $61 \mathrm{BCE}$, and during this period it has been suggested that all three were friends. Babcock, "The Early Career of Fulvia," 14-16. It should be noted, that this period falls during Fulvia's marriage to Clodius, and any friendship between the three men was likely the avenue by which Fulvia met the men who would later become her husbands.

${ }^{58}$ Antony had previously been married at least once, possibly twice. Babcock, "The Early Career of Fulvia," 11. Weigall, The Life and Times of Marc Antony, 135-6.

${ }^{59}$ Arkenberg, "Licinii Murenae," 341-4.

${ }^{60}$ It is also worth acknowledging that if Cicero's later accusation (Cic. Phil. 2.48) that Antony and Fulvia had an affair while she was married to Clodius is true, Fulvia and Antony may have loved each other, or at least felt passionate towards one another; perhaps not a logical, political reason for uniting through marriage, but certainly a human one, and one worth recognizing as a potential influence.
} 
strong-willed, political figure reached even the top of the Roman political spectrum with the dictator. ${ }^{61}$

While our ancient sources criticize Fulvia for failing in the roles of wife and mother, ${ }^{62}$ her objective failure or success as a Roman matron remains less black and white. The ideal Roman matron supported her husband, gave birth to and educated successful sons and daughters, managed the family's household including the household assets, ${ }^{63}$ and produced clothing. ${ }^{64}$ Elite matrons of this period often got highly involved with business, investing in new enterprises, running and organizing business ventures, and influencing economic markets. ${ }^{65}$ Whether this behavior was considered "proper" by moralists of the day, remains unclear. We have little record of Fulvia completing some of these tasks. For instance, Plutarch implies in the quote used to introduce this thesis that Fulvia could not be bothered to weave clothing or manage her house, "a woman who took no thought for spinning or housekeeping..." ${ }^{66}$ However, we know that after Antony was declared an enemy of the state in April of $43 \mathrm{BCE}$ and his rivals desired to extract revenge by robbing Fulvia and even killing her children, ${ }^{67}$ Fulvia sought assistance from Atticus, a close friend of her rival, Cicero. ${ }^{68}$ In seeking and gaining refuge and legal aid from Atticus,

\footnotetext{
${ }^{61}$ Weigall suggests that Fulvia "knew how to handle Caesar," and had done so during her marriages to Clodius and Curio. He also implies that Fulvia's direct intervention with Caesar on behalf of Antony fixed their quarrel in the year 47 BCE. Weigall, The Life and Times of Marc Antony, 136.

62 Plut. Ant. 10.1; Cic. Phil.2.95.

${ }^{63}$ Managing the household was especially important while one's husband was away on campaign or fulfilling a governorship in another province.

${ }^{64}$ Delia, "Fulvia Reconsidered," 198.

${ }^{65}$ Gaston Boissier, Cicero and His Friends: A Study of Roman Society in the Time of Caesar (London: Ward, Lock, and Co., 1970), 22-4.

${ }^{66}$ Plut Ant. 10.3.

${ }^{67}$ Nep. Att. 9.2.

${ }^{68}$ Atticus granting aid to Fulvia highlights two important characteristics of personal and political relationships during the Late Republic, these characteristics being complexity and changeability. Politics during this period were opportunistic and alliances shifted continually. This can most easily be seen in the changes in Antony's loyalty to Octavian between 44 BCE and 30 BCE. And evidence from Cicero's own letters suggest that he considered Antony a friend at certain points. In January of $49 \mathrm{BCE}$, Cicero referred to Antony as a friend, yet by early May he wrote about his frustration with Antony's immoral behavior and received advice from Atticus cautioning him against trusting Antony. However, several years later, in May of 44 BCE, Cicero wrote that he hoped to "keep my old
} 
Fulvia managed to protect her children, preserve her property, and defend the reputation of her husband, ${ }^{69}$ all of which are virtues of a good Roman wife and mother.

Fulvia also fulfilled the ideal requirements of motherhood. She gave birth to three children, ${ }^{70}$ all of whom could arguably be considered "successful" despite the vagueness of that term. Clodia, Fulvia's eldest child, married Octavian in 43 or $42 \mathrm{BCE}^{71}$ and though the marriage ended within three years, it was terminated due to political differences between Octavian and her mother, seemingly through no fault of Clodia's. The implied successfulness of Fulvia's next oldest child, Marcus Antonius Antyllus, can be concluded from both his father's trust in him to act as an ambassador, and Octavian's perception of the young Antony as enough of a threat at the age of seventeen to warrant execution. ${ }^{72}$ Fulvia's youngest, Iullus Antonius, escaped his brother's fate, growing up to become a praetor in $13 \mathrm{BCE}$ and consul in $10 \mathrm{BCE}$. Octavian, later Augustus, took young Iullus under his tutelage after the death of Antony. Why Octavian favored

established friendship with Antony," claiming that they had "never had a quarrel." Yet by September of 44 BCE, these letters demonstrate that Cicero no longer considered Antony a friend. These are simply some examples of the complexity and flexibility of these relationships. In the Late Republic an opponent could become an ally as easily as a friend became a foe, depending on how it served one's political interests.

Nepos reports that Atticus helped Fulvia out of the kindness of his heart, however Rex Stem notes that Atticus frequently took neutrality as a political tactic. He suggests that Atticus likely knew that helping Fulvia might benefit him down the road (Stem, The Political Biographies of Cornelius Nepos). It also is within the realm of possibility that Atticus felt a sense of obligation to aid Fulvia, as he had once considered Antony a friend. It is likely though, as I argue about Fulvia, that multiple motives influenced Atticus' decision.

${ }^{69}$ Nep. Att. 9.4.

${ }^{70}$ A number that if she had been alive after the enactment of Augustus' social reforms, would have granted her increased legal rights and additional autonomy.

${ }^{71}$ Our ancient sources do not give a specific date for this union, choosing instead to refer to the marriage as occurring after Antony and Octavian's first conflict and reconciliation. Dio, 46.56.3-4; Suet, Aug. 62.

72 Hallett, "Fulvia, mother of Iullus Antonius," 155. 
Iullus and did not see fit to execute him is unclear, ${ }^{73}$ but the clemency of his parents' rival allowed him to reach adulthood and engage in an active political career. ${ }^{74}$

Another popular social conviction imposed during this period was the belief that marriage was the ideal state, and that both men and women benefited from marital unions. ${ }^{75}$ For this reason, family often encouraged or required widows and divorced persons to remarry. However, if a woman married too many times she might be ridiculed or it might be implied that she was vain or had a voracious sexual appetite. ${ }^{76}$ Specifically how many husbands was too many, is unclear, however our sources, despite being filled with criticisms, do not challenge Fulvia for remarrying multiple times, so it seems safe to assume that three husbands was considered a respectable number.

Why in marriage did Fulvia do the things she did? Fulvia may have intended to start a riot after the death of Clodius in order to demonstrate her control over his collegia. Or perhaps she acted in an attempt to sway public opinion towards condemnation of Milo. She may have also been sending a message to Clodius' and her enemies about what fate awaited them. Or she may have simply been simply grieving. Likely though she strived for more than one objective. In that moment Fulvia was a grief-stricken widow, a mother fearful for her daughter who would grow up not knowing her father, a politician illustrating her power, and a daughter supported by

\footnotetext{
${ }^{73}$ Age was likely a factor in the clemency granted to Iullus, who was fifteen when Octavian executed his brother. Even though Iullus was only two years younger than Antonius Antyllus, his potential lack of participation in the war, implied by our sources' lack of commentary on him during this period, could suggest that Octavian viewed the younger son of his enemy as malleable, and able to be educated and groomed to be his own supporter. It is worth considering that more sentimental reasons may have factored into this decision as well, such as a sense of obligation or any nostalgic affection Octavian may have felt towards Antony, his former friend and ally.

${ }^{74}$ Hallett, "Fulvia, mother of Iullus Antonius," 149-51. Iullus' fate did not continue to be so fortunate though. After an affair with Augustus' (formerly Octavian) daughter, Julia, Iullus was charged with treason and sentenced to death in 2 BCE. Instead of facing execution, he chose to commit suicide. Dio suggests that Iullus had monarchal ambitions, perhaps hoping to marry Julia and become a regent over her children, Augustus' heirs (Dio 60.10.12-16). ${ }^{75}$ Rawson, "The Roman Family," 14.

${ }^{76}$ Karen K. Hersh, The Roman Wedding: Ritual and Meaning in Antiquity (Cambridge: Cambridge University Press, 2010), 103-4.
} 
the presence of her mother. All of these roles played into each other and undoubtedly influenced her decisions.

Soon after the death of her first husband, Fulvia married the close friend of her rival, Cicero, the man who defended Clodius' murderer. Curio's closeness with Cicero would seem to suggest that he would be an unusual spouse for Clodius' widow, yet Fulvia married him almost immediately once her period of mourning elapsed. Perhaps Fulvia felt significant love, passion, or respect for Curio. Or she may have viewed him through a more ambitious lens and determined that he had the potential to achieve her political goals. Fulvia's marriage to Antony poses similar questions of how our subject made matrimonial decisions, which she seemingly approached with political aspirations for her family, and possibly herself. 


\section{Fulvia, the Politician}

As illustrated in the previous sections, Fulvia's political ambitions and maneuvering began well before our ancient sources recognized her as a threat. ${ }^{77}$ In this section I discuss how and when Fulvia's political influence reached its peak. I address her fierce opponent Cicero, and the complexity of his statements about and against her. Fulvia's political rise, according to our ancient writers, grew over time, and was directly tied to her role as a wife, building into her last role, as a general.

Despite moments in our record of early political actions, like her tearful, mob-inciting eulogy, Fulvia's unofficial political career came into full force during her marriage to Antony. Her involvement in politics can be described as unconventional; rarely did women intervene in political affairs, at least according to our sources, and when they did it was typically enacted by raising a concern to a female relative of a politician who could privately bring the issue to her

\footnotetext{
${ }^{77}$ Plutarch (Ant. 10.3) and Appian (BC 44.4) suggest that Fulvia's influence began with her marriage to Antony, and not earlier like I argue in the previous chapters.
} 
husband, son, brother, or other kin. ${ }^{78}$ Fulvia did not always engage in politics in this way. ${ }^{79}$ And with her deviation from the norms rose detractors, the most famous being Marcus Tullius Cicero.

Though the animosity shared between Fulvia and Cicero likely began after Cicero's defense of Milo, ${ }^{80}$ his vocal denigrations of her began in earnest after her marriage to Antony, his former friend turned rival, in 47 or $46 \mathrm{BCE} .{ }^{81}$ Cicero's arguments against Fulvia rely on discrediting her morality, a popular tactic of Roman oratory during the period. The public and fellow politicians viewed claims of immorality as legitimate concerns, therefore moral condemnations could be taken as grave insults, and they were Cicero's favorite method of attacking his opponents. However, the public understood exaggerated claims of immorality to be what they were: hyperbole. ${ }^{82}$ Additionally, the public expected a certain level of amusement and entertainment from speeches and writings of their public figures, which certainly encouraged politicians to exaggerate rumors and overemphasize their opponents' flaws. ${ }^{83}$

In his Philippics, a series of fourteen speeches given by Cicero in front of the Senate between September of 44 BCE and April of 43 BCE, Cicero attacked Antony, often using Fulvia to do so. In his second speech in the series, Cicero alludes to Fulvia as he warns Antony about

\footnotetext{
${ }^{78}$ We see this in Hortensia's attempt to fight the taxation on 1400 of Rome's elite women in 42 BCE, a topic I shall discuss further later. Hortensia went to Antony's mother, Julia, and Octavian's sister, Octavia, for aid. She also turned to Fulvia, but was rebuffed. (App, BC. 4.32-34; Val, Max. 8.3.3; Quintil. 1.1.6) Additionally, during war women could participate in public speaking, a right of which later, imperial women like Livia and the Agrippina's took advantage. Joyce Salisbury, Encyclopedia of Women in the Ancient World (Santa Barbara: ABC-CLIO, 2001), 161.

${ }^{79}$ She may have pursued political goals in this way as well, but we have no surviving records of such interactions, and we know she used other, less acceptable methods in her political dealings, such as public speeches (App, $B C$. 5.2.14, 5.3.19; Dio, 48.10-14), private meetings with diplomats and politicians, and possibly even prostituting herself for political transactions. (Cic. Phil. 2.95)

${ }^{80}$ Clodius and Cicero had been enemies before this, though none of our sources, including Cicero himself, speak to whether this dislike extended to Fulvia. In fact, Cicero's treatment of Fulvia during Milo's trial in 52 BCE offered more neutrality and respect than his later writings gave her. Welch, "Antony, Fulvia, and the Ghost of Clodius," 188. ${ }^{81}$ Welch, "Antony, Fulvia, and the Ghost of Clodius," 186.

${ }^{82}$ Isak Hammar, "Making Enemies: the Logic of Immorality in Ciceronian Oratory" (PhD diss., Lund University, 2013), 18.

${ }^{83}$ Hammar, "Making Enemies," 20.
} 
the death of her previous husbands: "But who was ever found before, except Publius Clodius, to find fault with my consulship? And his fate indeed awaits you, as it also awaited Caius Curio; since that is now in your house which was fatal to each of them." ${ }^{84}$ He claims in the same speech that Antony had engaged in an affair with Fulvia during her marriage to Clodius, ${ }^{85}$ and that Fulvia sold pieces of Rome and possibly her body for political gain. ${ }^{86}$ In another line from the Second Philippic, Cicero reveals his desire for Antony to be dead. Referring once again to the fate of her previous husbands, Cicero seems to humorously implore Fulvia to cause the death of another husband, "In truth, that wife of yours, who is so far removed from covetousness, and whom I mention without intending any slight to her, has been too long owing her third payment to the state.... ${ }^{, 87}$ Fulvia of course did not cause either of her first two husbands' deaths, but these quotes serve as examples of how Fulvia's role as a wife impacted both her political activity and that of her husband.

And Fulvia was nothing if not politically active during this period. Our ancient sources report that from early in their marriage, Fulvia allowed Antony use of Clodius' collegia, ${ }^{88}$ however they do not bother to clear up any vagueness surrounding this claim. How much involvement our subject maintained with Clodius' gangs is unclear. Her implied position as their leader may have been ceremonial. Or she may have been intimately embroiled in organizing their actions, particularly how they influenced politics. Unfortunately, our limited evidence for

\footnotetext{
${ }^{84}$ Cic. Phil. 2.11. There is no evidence to suggest that Fulvia had any hand in the death of her husbands, though it made for a bold and exciting claim, presenting Fulvia at worst as a cold-hearted killer, or at best as a token of incredibly bad luck.

${ }^{85}$ Cic. Phil. 2.48.

${ }^{86}$ Cic. Phil. 2.95.

${ }^{87}$ Cic. Phil. 2.113.

${ }^{88}$ Plut, Ant. 11.3.
} 
Fulvia's life, and its brevity, ensures our uncertainty in this, as in many aspects of Fulvia's complicated life.

Around the same time, she also supposedly mended the relationship between Caesar and Antony in $45 \mathrm{BCE}$, after urging Antony to make peace ${ }^{89}$ Antony's carefree lifestyle of drinking and dalliances had strained their relationship, however his marriage to Fulvia and her advice to seek reconciliation with Caesar seemed to resolve the minor conflict. Later Fulvia spoke out against Cicero and defended Antony during the months in which Cicero gave the Philippics. After the completion of the speeches against her husband in April of $43 \mathrm{BCE}$, she pleaded with the Senate not to declare Antony an enemy of the state. ${ }^{90}$ The Senate did so anyway, forcing Fulvia to seek shelter with Atticus. Nepos reports that Atticus did this out of the kindness and generosity of his character, however as discussed previously, ${ }^{91}$ the complexity of personal and political relationships in the Late Republic and the potential for Atticus to benefit politically or financially likely also influenced his altruism. ${ }^{92}$

With the formation of the Second Triumvirate and the march on Rome made by Julius Caesar's young heir, Octavian, Antony's status as an enemy of the state was dismissed. To solidify the union between Antony and Octavian, Fulvia's daughter, Clodia, was betrothed to the young triumvir. Our ancient sources report that Antony and Octavian organized the union, ${ }^{93}$ however, the likelihood that Antony and Octavian arranged this marriage without Fulvia's approval is slim. Considering the control Fulvia exercised in various aspects of her own and her

\footnotetext{
${ }^{89}$ Weigall, The Life and Times of Mark Antony, 138-9.

${ }^{90}$ App, BC. 3.8.51.

91 See note 52.

92 Nep. Att. 9.2-4; H. Lindsay, "The Biography of Atticus: Cornelius Nepos on the Philosophical and Ethical Background of Pomponius Atticus," Latomus 57, no. 2 (1998): 324-36. It should be noted that Nepos was good friends with both Atticus and Cicero, and likely had motive to portray Atticus in a positive light. This is not to say that Atticus was not acting out of kindness, but it is unlikely that was his only motive.

93 Plut, Ant. 20; Dio, 46.56.3-4; Suet, Aug. 62.
} 
husbands' lives, it would be anomalous for her to have not been a powerful voice regarding the decision to betroth her daughter by Clodius. This particular political move fascinates because it shows the complexity of Fulvia as a mother, wife, and politician. This marriage offered a stronger political alliance for her husband and an advantageous and ambitious spouse for her daughter. ${ }^{94}$ Therefore the union of Clodia and Octavian likely suited her interests as a mother, wife, and political actor simultaneously.

Toward the end of the very busy and chaotic year of $43 \mathrm{BCE}$, Octavian and Antony issued proscriptions for the conspirators in the assassination of Julius Caesar. Over the course of two months, bloodshed filled the streets as enemies of the Triumvirate were hunted and executed. One such enemy was Cicero. According to our sources, when Cicero's killers delivered his head to Antony and Fulvia, Fulvia spat on it and pierced the dead man's tongue with one of her hairpins. ${ }^{95}$ The symbolism of piercing the vicious orator's tongue is clear, but what reason did she have to do such a thing? Revenge and vindictive feelings towards the man who disparaged herself, her father, her ancestors, and her husband are fair assumptions, but they are not necessarily the only potential motives. She might have pierced his tongue as a display of loyalty to her husband. Or perhaps even more generally, Fulvia could have pierced his tongue as a warning to others who might have considered speaking out against her or her loved ones.

In the summer of $42 \mathrm{BCE}$, Antony and Octavian sailed eastward, in order to regain control over Rome's eastern territories. Though they charged the third member of their Triumvirate, Marcus Aemilius Lepidus, with the task of managing the city while they were gone, Dio reports that it was Fulvia who in fact "ruled Rome." ${ }^{.96}$ For Fulvia 'ruling Rome' consisted of

\footnotetext{
${ }^{94}$ Fulvia, if her own choices of spouses are any indication, seemed to value ambition and potential political success in suitors. Therefore it would make sense that she would desire the same for her daughter.

${ }^{95}$ Dio 47.8.1-5; App, BC. 4.29.

${ }^{96}$ Dio 48.4.1-6.
} 
convincing the Senate to grant her brother-in-law, Lucius, a triumph, using her wealth to manipulate politics, and taking advantage of an informal patronage network in the form of complex political relationships and her collegia. ${ }^{97}$

One of the more infamous stories of Fulvia during this period of her heavy influence over Roman politics is the account of how she turned away Hortensia. Hortensia, a fellow elite matron, came to Fulvia's home hoping to convince her to persuade Antony to throw out a proposed tax on the wealthiest 1,400 women in Rome. Instead of hearing the other woman's case, Fulvia dismissed Hortensia and offered her no aid. ${ }^{98}$ Our ancient sources use this incident as an example of Fulvia's cruelty, however it could also be viewed as an act of loyalty. The Triumvirs proposed the tax to fund their war against Caesar's assassins who had fled to the east. If Fulvia knew how important defeating the assassins was to her husband, and knowing that the war required more funding, why would she help Hortensia? As Antony's wife and ally, she had plenty of reasons to support her husband over one of her peers. Additionally, Fulvia tended to act politically based on logical estimations of advantage, meaning that if she saw little to no advantage to aid Hortensia, she had no reason to take the risk.

Though germinating since her youth, Fulvia's unofficial political career really took shape during her marriage to Antony. Whether Fulvia's aspirations propelled Antony, or Antony's already notable career offered Fulvia a platform is unclear, but together they made a formidable and ambitious team. And even as Fulvia pushed the limits of alliances and her influence to the brink of war, her responsibilities as a wife and politician remained essential.

\footnotetext{
97 Dio 48.4; Cic Phil. 2.95.

${ }^{98}$ App, BC. 4.32-34; Val, Max. 8.3.3; Quintil. 1.1.6.
} 


\section{Fulvia, the General}

Before analyzing Fulvia's role as a general in the Perusine War, we must first understand the complex military and political circumstances that preceded the conflict. In this section, I explore the lead up to the war, how Fulvia is portrayed by extant ancient records, and what role Antony may or may not have played in the conflict. I also discuss the importance of the surviving archaeological evidence from the war. As in every preceding section, this chapter strives to show how the motives assumed by our ancient scholars are not necessarily completely inaccurate, but at least oversimplified and likely do not demonstrate the whole picture.

In the fall of 42 BCE Antony and Octavian met two of Julius Caesar's assassins - Marcus Junius Brutus and Gaius Cassius Longinus - and their forces in battle on the western plain outside the city of Philippi in Macedonia. After the initial battle ended in draw, a second battle 
weeks later on the same field resulted in victory for Antony and Octavian. The Triumvirs then decided that Antony would remain in the East to manage and organize Rome's interests while Octavian would return to Rome to oversee the confiscation of land and resettlement of their veterans. ${ }^{99}$

Eighteen communities in Italy were selected to fulfill the settlement needs of the 40,000 veterans. These cities openly protested this program, suggesting that it be expanded to lessen the burden. This idea spread panic to other communities, causing landowners from across Italy to travel hastily to Rome so they could advocate for their rights. Octavian attempted to propose compromises that would appease the landowners targeted by the resettlement plans, but those only succeeded in angering the veterans, who began to doubt whether the young Triumvir would acquire the land promised to them. ${ }^{100}$

During this turmoil our sources, both ancient and modern, claim that Fulvia - with the aid of Antony's brother, Lucius Antonius, and Antony's agent, Manius - plotted to use the chaos to her husband's benefit. Fulvia, blaming Octavian for the disruption of their settlement, brought her children before the veterans and pleaded with them to remember Antony. At the same time these three political actors are reported to have championed the rights of the landowners and appealed to their respect of Antony and his many victories. ${ }^{101}$

As a result, Fulvia and Lucius raised eight legions of soldiers loyal to Antony. ${ }^{102}$ Manius revealed a letter from Antony - whether a forgery or a real piece of correspondence is unclear -

\footnotetext{
${ }^{99}$ Ronald Syme, The Roman Revolution (Oxford: Oxford University Press, 2002), 203-6.

100 Syme, The Roman Revolution, 207; Appian 5.3.12.

101 Babcock, "The Early Career of Fulvia," 21; Syme, The Roman Revolution, 208; Delia, "Fulvia Reconsidered," 205; App, BC. 5.2.14, 5.3.19; Dio, 48.10-14.

102 Syme, The Roman Revolution, 209; App. BC 5.23.92; Dio 48.5-6. Appian and Dio imply that the soldiers gathered by Fulvia and Lucius were loyal to Antony alone, but they also might have been spurred by disapproval of Octavian or loyalty to the citizens distraught by the land settlements.
} 
endorsing war if necessary to defend his dignitas. ${ }^{103}$ Under these circumstances, Lucius and Fulvia engaged in a few battles with Octavian's troops before Lucius took a defensive position within the fortified city of Perusia (modern day Perugia, Italy); Octavian's troops subsequently laid siege.

Fulvia's whereabouts during this siege are unclear. After raising legions with Lucius, our sources recount that Fulvia donned a sword, gave orders, and lectured the troops while at Praeneste, a city approximately twenty miles east of Rome. Dio describes Fulvia as being the sole commander during the occupation of Praeneste. Following that occupation, Fulvia travelled to Gaul to secure reinforcements. ${ }^{104}$ Appian tells us that Fulvia rallied generals and reinforcements in Gaul while Lucius fought Octavian at Perusia. ${ }^{105}$

If our sources are to be taken at their word and Fulvia did indeed carry a sword, such a revelation forces us to wonder if she knew how to use it. The sword may have served as decoration, or as a symbol of Fulvia's authority. Perhaps Fulvia used the addition of a sword to intentionally embrace the masculine portrait her enemies had already begun to paint. Like many theories posed in this work, this would be hard to prove. But it is worth questioning how aware Fulvia was of her reputation, and how she may have used it to her advantage.

If the sword she wore was not merely decorative then we are faced with an equal number of fascinating yet unanswerable questions concerning who might have taught Fulvia to fight, for what purpose she might have been taught, and whether she ever used her blade in combat. These are captivating contemplations, however their relevance is undermined by our lack of

\footnotetext{
103 Appian 5.29.112.

${ }^{104}$ Bauman, Women and Politics in Ancient Rome, 88; Dio 48.10.3-4; App. BC 5.19. According to Dio, Octavian took particular offense to Fulvia giving orders and acting as a commander. Velleius Paterculus gives a similar account (Paterculus, Historiae, 2.74).

${ }^{105}$ App 5.26.103. Where she travelled in Gaul in search of allies remains without comment by ancient scholars.
} 
information about the circumstances and intentions of Fulvia when she donned this unusual accessory. Since we have no accounts of Fulvia ever using a sword, in war or any other occasion, the most logical conclusion would be that wearing a weapon was a method of asserting her authority. If Fulvia had ever raised a sword - or any weapon - on a field of battle, it seems highly unlikely that not a single ancient source would mention such a scandalous deed, especially since it would provide more ammunition with which to discredit and disparage her.

In any case, such direct involvement in military proceedings was unprecedented for a woman in this period. While the Romans encountered and fought warrior women from other societies, there is no record of Roman women serving in the military. ${ }^{106}$ Roman women, in the form of wives, nurses, merchants, and prostitutes, were known to follow the army on campaign, but there was no precedent for a woman in command. ${ }^{107}$ Prior to the Perusine War, Fulvia travelled with Antony on military campaign at least once - where in Brundisium in 44 BCE, she witnessed her husband order the execution of a number of his soldiers. Cicero and Dio report that blood splattered Fulvia's face due to her close proximity to the executions. ${ }^{108}$

Having accompanied Antony on campaign and watched him acting as a military leader, we can reasonably assume that Fulvia could have gained some understanding of how to command, discipline, and organize legions. Fulvia's leading of the occupation of Praeneste implies not only that she gave commands, but that they were followed. This obedience could have stemmed from the troops' loyalty to Antony, though due to Antony's absence and his

\footnotetext{
${ }^{106}$ Linda Grant DePauw, Battle Cries and Lullabies: Women in War from Prehistory to the Present (Norman: Univ. of Oklahoma Press, 2000), 67.

${ }^{107}$ DePauw, Battle Cries and Lullabies, 67-80.

${ }^{108}$ Cic Phil 3.4; Dio 45.13, 45.35. These ancient sources do not comment on Fulvia's reaction to this violent event, though some of the more modern sources take these accounts as evidence that Fulvia reveled in literal bloodshed. Weigall, The Life and Times of Marc Antony, 250; Balsdon, Roman Women. 55.
} 
apparent indifference towards the conflict, such deference was plausibly an illustration of their loyalty to Fulvia herself. ${ }^{109}$

Antony's role in the conflict, if any, is also uncertain. Fulvia and Lucius certainly worked in the interest of Antony - Lucius even stated as much at Perusia ${ }^{110}$ - but whether they acted with his knowledge, direction, and support is less clear. Examining Antony's complicity or innocence in the Perusine War serves a worthwhile purpose outside of assigning blame or determining objective participation. By studying Antony's involvement - or lack thereof - we can propose some conclusions about Fulvia's participation. For example, if Antony masterminded the plot and ordered Fulvia and Lucius to execute it, we can extrapolate that Fulvia demonstrated loyalty and faith towards her husband, as well as Antony likely harboring trust in her ability to enact his vision. On the other hand, if Antony had no knowledge of or involvement in the war, it implies more initiative on Fulvia's part - and perhaps more ambition too, if she sought a future in which her husband was the sole ruler of Rome.

The most reasonable estimation of Antony's complicity falls somewhere in the middle of these two extremes. Likely, Antony supported his wife and his brother's efforts, knowing that if they succeeded he would gain significant power. In this regard, the distance between Antony and the events occurring in Rome served him well. Considering the effort and time required in transporting missives around the Mediterranean, ${ }^{111}$ it would have been easy for Antony to claim plausible deniability. Leaving our most probable circumstance: that he intentionally kept himself

\footnotetext{
${ }^{109}$ It should be noted that there is a possibility that our ancient historians overstated Fulvia's leadership and influence in order to undermine the legitimacy of that side of the conflict and those who they claim served under her command. This is less likely, in my estimation, than theses sources commenting on it because of its unprecedented nature, but it remains a potential explanation.

${ }^{110}$ Syme, The Roman Revolution, 211.

${ }^{111}$ Richard J. A. Talbert and Fred S. Naiden, Mercury's Wings: Exploring Modes of Communication in the Ancient World (Oxford: Oxford University Press, 2017).
} 
out of the conflict, knowing that if they should fail he could use his detachment as a testament to his innocence. In this scenario, Fulvia could be seen as both loyal to Antony and ambitious for their imagined future, with initiative independent of her husband. Whether Fulvia and Lucius knew that Antony would use them as scapegoats when their war failed though is as unclear as Antony's true participation in the conflict.

On the topic of motive, our ancient sources claim that Fulvia instigated the Perusine War because she was jealous of her husband's extramarital dalliances while he was in the East. While this is not an impossible explanation, the implication that it was her only reason for stirring up trouble infantilizes her. This was not the first time Antony had been unfaithful while they were married, ${ }^{112}$ however in previous moments of her husband's infidelity she did not start wars or lead revolutions. With this knowledge it would then be unfair to assume that Fulvia's personal disappointment or feelings of betrayal were the sole cause of the Perusine War.

There exists many more plausible factors and reasons which may have motivated Fulvia to support Lucius and raise an army against Octavian. For instance, she may have done so in a display of loyalty to her husband. Antony stood to gain much if Fulvia and their allies could discredit or destroy Octavian and his supporters. Regardless of Antony's involvement or lack of involvement, Fulvia's actions could have easily been motivated by love, loyalty, or devotion. Or she may have been motivated by ambition; either for herself, her husband, her children, or all of them together. Perhaps as a wife and mother she hoped to build a dynasty for her husband to rule and her children to inherit. She may have been moved to action by observing Octavian's tenuous hold on his power during the debates over the settlement of the Philippi veterans. As a shrewd political player, if she perceived Octavian's position as weak and vulnerable to attack, such a

${ }^{112}$ Cic Phil. 2.77; Plut Ant. 10.4-5. 
revelation could have convinced her that it was the right time to plot against him. Additionally, we cannot disregard the possibility that Fulvia may have had a sincere desire to help the citizens whose land would be taken in order to settle the veterans. However, it seems most probable that several of these factors, and likely others unknown to us, all contributed to Fulvia's involvement in the conflict.

One of the extant records from the Perusine War regarding Fulvia's motives is a poem recounted by Martial, though he attributes its origin to Octavian himself. This poem, supposedly written by Octavian during or shortly after this conflict, gives us important insight into how the war, and those who fought on the opposing side, may have been viewed by Octavian and his supporters. This poem shows us how Octavian hoped to convince the public they should view the conflict, and by association, Fulvia. The poem begins in Martial's words:

Read six bawdy verses of Augustus Caesar, ill-tempered one, you who read Latin words in a disapproving mood..$^{113}$

As Martial explains, the poem is six sexually explicit verses that detail Octavian's perception of why Fulvia started the Perusine War. The poem claims that Fulvia's frustration with Antony's infidelity caused her to give Octavian an ultimatum - he could either fight her or have sex with her.

Because Antony fucked Glaphyra, Fulvia decided on this punishment from me, that I also fuck her. ${ }^{114}$

The verses explain that Octavian viewed the idea of having sex with Fulvia as a punishment, and that he valued his mentula (penis) too dearly to consider such an option.

\footnotetext{
${ }^{113}$ English translation by Hallett in "Fulvia, mother of Iullus Antonius," 152; Martial 11.20 (line 1-2).

${ }^{114}$ English translation by Hallett in "Fulvia, mother of Iullus Antonius," 152; Martial 11.20 (line 3-4).
} 
Why deny that my prick is dearer to me than my life itself? ${ }^{115}$

He also compares having sex with Fulvia to engaging in anal sex with Manius, and states that both are equally distasteful.

That I am to fuck Fulvia? What if Manius should beg me to fuck him in the asshole, would I do that? Not, I think, if I should have any taste. ${ }^{116}$

In the last line Octavian orders the war trumpets to sound - illustrating that he would rather fight than have sexual relations with Fulvia. ${ }^{117}$

This risqué poem is important for a few reasons. First, it portrays Fulvia as a masculine and sexually aggressive figure. Propositioning Octavian in order to punish her husband was an essentially masculine exercise, in that Roman men were supposed to be the initiators of sexual relations. ${ }^{118}$ Additionally, the vulgar language attributed to Fulvia in the verses is used to further illustrate her sexual deviancy and failure as a proper Roman matron. It also ascribes a malicious jealousy to Fulvia over the affairs of her husband, which drives her to stir up trouble. This perception of Fulvia and motive for initiating war are common among the ancient sources. ${ }^{119}$ Perceptions of Fulvia as overly masculine continued to be common among later authors such as Plutarch and Appian. Velleius Paterculus even claims that she "had nothing womanly about her save her body." ${ }^{120}$ Claims that she started the war out of jealousy or in an attempt to force Antony to return to Italy from the East can be found in Appian, Cassius Dio, and Plutarch. ${ }^{121}$

\footnotetext{
115 English translation by Hallett in "Fulvia, mother of Iullus Antonius," 152; Martial 11.20 (line 7-8).

${ }^{116}$ English translation by Hallett in "Fulvia, mother of Iullus Antonius," 152; Martial 11.20 (line 5-7).

${ }^{117}$ Hallett, "Fulvia, mother of Iullus Antonius," 152; Martial 11.20.

118 Judith P. Hallett, "Perusine Glandes and the Changing Image of Augustus," AJAH 2, no. 2 (1977): 162.

${ }^{119}$ Hallett, "Perusine Glandes," 160-3.

${ }^{120}$ Hallett, "Perusine Glandes," 152-3; Paterculus, Historiae, 2.74.

${ }^{121}$ App, BC 5.2.14; Dio, 48.10-14; Plut. Ant. 10.3.
} 
The second significance of this poem lies with its origin during a period between $44 \mathrm{BCE}$ and $32 \mathrm{BCE},{ }^{122}$ in which Octavian actively sought to change the perception of himself as weak and cowardly - a reputation additionally hindered by the rumors that Octavian not only engaged in homosexual relations, but that he took the passive role in these activities and allowed himself to be penetrated. ${ }^{123}$ With this understanding of Octavian's goals, distinguishing this poem as a work of propaganda is relatively easy. Through highlighting Fulvia's masculine and deviant activities, the poem uses her as a foil - managing to both condemn Fulvia while highlighting Octavian's sexual desirability, military prowess, and courage. ${ }^{124}$

Valid skepticism can be posed as to whether Octavian authored these verses, especially considering his later social reforms and strictness in regard to moral sexual conduct. However, as Hallett points out, the meter and style of the poem are both consistent with the period in which it was supposedly composed and similar to a poem written by Octavian around the same time. ${ }^{125}$ Additionally, Suetonius references a collection of Octavian's poems that existed in his lifetime, implying that epigrams composed by Octavian were not uncommon. ${ }^{126}$ In the context of Octavian's reputation prior to the Perusine War as effeminate, weak, and cowardly, however, the composition and distribution of this poem as propaganda to show the young Triumvir as manly, virile, and not submissive to women makes it reasonable to accept Octavian as the author. Since the poem shows Octavian refusing Fulvia's sexual advances and not acting immorally, it does not contradict his later reforms enough to merit complete dismissal of Octavian as the originator.

\footnotetext{
122 Hallett, "Perusine Glandes," 160-1.

${ }^{123}$ Hallett, "Perusine Glandes," 157-8. Culturally, penetration was viewed as a masculine act, so a man allowing himself to be penetrated would often be viewed as effeminate and weak. There were also rumors that Octavian prostituted himself to achieve his political objectives, a sexually immoral and 'womanish' behavior (Suet. Augustus, 68).

${ }^{124}$ Hallett, "Fulvia, mother of Iullus Antonius,"153; Hallett, "Perusine Glandes," 161-3.

125 Hallett, "Fulvia, mother of Iullus Antonius," 152.

${ }^{126}$ Suet. Augustus, 85.2.
} 
This poem also endeavors to portray Fulvia as less politically and militarily significant by reducing her to a jealous and manipulative figure whose only motive for starting the war was a lack of sex - an idea that our later literary sources and archaeological evidence contradict. ${ }^{127}$ This may have been the result of Octavian attempting to downplay the severity of the conflict as a whole, since it would continue to prove "a perpetual source of embarrassment" for him. ${ }^{128}$ Octavian's, or rather Augustus' Res Gestae skips over the Perusine War entirely, as if the whole affair never occurred. ${ }^{129}$

Unfortunately for Octavian, we have significant archaeological finds supporting the fact that the conflict did transpire. One form of this surviving archaeological evidence from the siege of Perusia is lead sling bullets, also referred to as glandes. Sling bullets were a common projectile weapon utilized by both Ancient Greek and Ancient Roman armies. Ammunition for slings could be any small projectile - such as river stones, clay, or limestone. However, castable metals such as lead were found to be most effective due to their relative density, weight, and size. $^{130}$

Lead glandes varied in size from three to six centimeters in length and generally weighed between twenty and fifty grams. ${ }^{131}$ Inscriptions were common on the surface of these bullets, and ranged from the name of the bullet's maker, to the name of a slinger's legion or homeland, to insults that would be figuratively and literally hurled at the enemy. These inscriptions were made by carving one's message into the clay mold - requiring the message to be carved backwards in

\footnotetext{
${ }^{127}$ Dio 48.4.1; Plut Ant. 10.1; App BC 5.19.75.

${ }^{128}$ Hallett, "Perusine Glandes," 163.

129 Hallett, "Perusine Glandes," 163-4.

${ }^{130}$ Manfred Korfmann, “The Sling as a Weapon,” The Scientific American 229, no. 34 (1973): 37-8; John Ma, “A Note on Lead Projectiles (Glandes, Molybdides) in Support of Sling Bullets: a Reply to T. Rihll," Journal of Roman Archaeology 23 (2010): 427-28.

${ }^{131}$ Lead sling bullets were typically prolate spheroids, in other words, shaped similarly to little, metal, American footballs.
} 
the clay so that the embossed inscription is legible on the bullet. Casting lead sling bullets in clay molds allowed for consistency in size and weight, and therefore general efficacy, as well as the potential for mass-producing bullets with inscriptions. ${ }^{132}$

The uniqueness of the projectiles found at Perusia lies within the lewd epigraphs cast into the bullets themselves, which offer insults aimed at the leaders of the conflict - namely Octavian, Fulvia, and Lucius Antonius. The insults found on these bullets are explicit, such as describing intent to penetrate the targets in the anus or clitoris. While inscriptions on these missiles were common, according to Hallett no ancient sling bullets outside of those found at Perusia contain messages sexual in nature or referencing sexual organs. ${ }^{133}$

The bullets created to wound Octavian's pride refer to him by the feminine form of his name, Octavia. In addition to making implications about Octavian's effeminacy and purposely not referring to him as "Caesar" like his own troops did, these projectiles latched on to the popular perception of the young Triumvir as weak and sexually passive. One surviving glans accuses Octavian of performing fellatio, another claims that Octavian's anus is loose (laxe) - a reference to the rumors of his affairs with men. ${ }^{134}$

The glandes bearing inscriptions aimed at Fulvia threatened to hit her in the anus and clitoris. The implication of a bullet inscribed with the intent of attacking Fulvia in her clitoris lies with the idea that such a target would be the most crippling place to strike her - an assumption tied to Roman perceptions of the clitoris as the center of female hypersexuality and

\footnotetext{
${ }^{132}$ Korfmann, "The Sling as a Weapon," 39-41. The sling bullets used by the Roman legions in the Perusine War were larger than those used by their Greek predecessors, between five to six centimeters in length and weighing around thirty to thirty-five grams. In the care of a skilled slinger, glandes could purportedly strike a target at a distance of 200-400 meters and were as deadly as arrows.

133 Hallett, "Perusine Glandes," 154.

${ }^{134}$ Hallett, "Perusine Glandes," 152-3; Hallett, "Fulvia, mother of Iullus Antonius," 151.
} 
immorality. ${ }^{135}$ These insults are likely tied to prior accusations made by Cicero of Fulvia's infidelity with Antony while married to Clodius, as well as rumors that she "bought and sold" her body in political transactions. ${ }^{136}$ By declaring intention to strike Fulvia's clitoris, this bullet both reminds observers of Fulvia's rumored infidelity and immorality, and illustrates a desire to hurt her - and potentially correct her rumored hypersexual behavior - by damaging and disfiguring her sexual anatomy.

In addition to suggesting the relevance of Fulvia's reported immorality on the minds of her political and military opponents, this glans wields special significance as it bears the earliest surviving usage of the Latin word landica (clitoris). ${ }^{137}$ According to Hallett, landica did not appear frequently in later sources; being recorded only five times in total among our extant sources, and never by a "respectable Latin author."138 Landica may not appear in any extant texts by the "respectable" authors, but our analysis of Octavian's bawdy verses above contradicts the idea that "respectable" people, the elite, did not use explicit language. This is not to suggest that Octavian or Lucius or Fulvia stayed up late at night carving insulting puns ${ }^{139}$ into glandes molds, though that is an amusing image. ${ }^{140}$ However, we must acknowledge such a scenario as a

\footnotetext{
${ }^{135}$ Hallett, "Perusine Glandes," 157.

${ }^{136}$ On Fulvia's infidelity according to Cicero (Cic. Phil 2.48); on the implied political prostitution (Cic. Phil 2.95).

${ }^{137}$ Although not drastically important to my argument, it is worth noting that this early usage of landica occurs in a direct threat of violence to Fulvia's person, illuminating the prevalence of violence, and threat of violence, against women that has persisted throughout history and into modern day. Often this violence or threat of violence is aimed at women's genitalia or perceived impropriety due to sexual behavior, both of which are exhibited in this sling bullet inscription.

${ }^{138}$ Hallett, "Perusine Glandes," 154.

${ }^{139}$ Hallet ("Perusine Glandes," 156) discusses these sling bullets as puns in detail. Suffice it for our purposes here that I quote her exceptional analysis, "Like the playful poems, the messages on the glandes were obviously conceived in levity, and levity of a literary nature. ...glans served as the technical Latin term for both lead slingbullet and the tip of the penis... In other words, these inscribed glandes operate as a jeu de mots- one not dissimilar to the above-mentioned portrayals of the membrum virile as a fighting weapon, which pun on the sexual connotations of military vocabulary... These double entendres serve as the main source of humor in their respective epigrams; the existence of such Priapean puns would suggest that the Perusinae glandes were also created with a primarily paronomastic purpose."

${ }^{140}$ We know this to be especially true of Fulvia, who according to our sources never steps foot in Perusia during the conflict (App. BC 4.29-4.32, 5.2-5.3).
} 
possibility. It seems significantly more plausible that the soldiers on both sides were responsible for the inscriptions, especially since we know that some, if not most, of Roman soldiers of this period were literate. ${ }^{141}$

Knowing the creators of these bullets and inscriptions is valuable because such information offers insight to the potential motivations for their creation, as well as the popular perceptions of the leaders on both sides of the conflict. If Fulvia herself carved the inscriptions into the molds and cast the glandes - an incredibly unlikely scenario due to Fulvia's geographical separation from the siege at Perusia - this would demonstrate impressive dedication and spite, as well as a vocabulary that was unbecoming of an elite Roman woman and an efficient method of delivering the bullets to Lucius and the troops at Perusia. If her soldiers, either those traveling with her or those at Perusia, created them on her command, it reveals a willingness to obey her orders. If her soldiers created these bullets without her command, either through her indifference or her absence, it shows a significant amount of loyalty on behalf of the troops and likely a desire to defend her reputation. The same circumstances hold true in considering the creation of glandes by soldiers under the command of Octavian or Lucius.

Logically it seems unlikely that both sides thought of inscribing such specific and explicit insults on their sling bullets independent of each other. Therefore one army must have created some inscribed bullets, fired them at the other side, and prompted their opponents to respond with their own insult-wielding projectiles in turn. ${ }^{142}$ The literal and figurative flinging of these insults may have also been escalating. This could have occurred by one side hurling a mild insult, such as "L. Antoni calve" (L. Antony is bald), ${ }^{143}$ prompting the opposing army to respond

\footnotetext{
${ }^{141}$ Sara Elise Phang, "Military Documents, Language, and Literacy," in A Companion to the Roman Army, ed. Paul Erdkamp (Sussex: Wiley-Blackwell Publishing, 2007), 299-300.

${ }^{142}$ Hallett, "Perusine Glandes," 154.

${ }^{143}$ Hallett, "Perusine Glandes," 153.
} 
with a stronger insult, such as "Salve Octavi felas" (Octavian performs fellatio), ${ }^{144}$ inciting an even stronger response from the other side, such as "Fulviae landicam peto" (I seek Fulvia's clitoris). ${ }^{145}$ This does not serve as my hypothesis as to which side began the battle of wits; rather it should be viewed as simply an example of how this inscriptive exchange may have been escalatory in nature. ${ }^{146}$

Importantly though, the repetition of insults aimed at Fulvia suggests that Octavian's troops recognized that Fulvia was one, if not the, leader of the opposing side. This concept is even more impressive considering that Fulvia never stepped foot in Perusia during the war, suggesting that she had such a reputation as a leader and instigator of the conflict that she was targeted via sling bullet even though she was hundreds of miles from the fields on which the sling bullets were hurled. They labelled Fulvia "the enemy" and implied that she commanded the forces at Perusia, not Lucius. ${ }^{147}$

Outside of perceptions of Fulvia as a leader of the troops holed up in Perusia, she may have also been targeted due to her potential role as a symbol for the soldiers loyal to Antony. This symbolic role is supported by her visage appearing on coins commissioned by Antony as early as 43 BCE. ${ }^{148}$ These artifacts depict Fulvia as the goddess Victoria and they serve as the earliest known coins bearing the image of a living Roman woman. There were five different

\footnotetext{
${ }^{144}$ Hallett, "Fulvia, mother of Iullus Antonius," 151.

145 Hallett, "Fulvia, mother of Iullus Antonius," 151; Hallett, "Perusine Glandes," 155-7.

146 This example also only uses the decipherable inscriptions of the sling bullets found by archaeologists. There may have been other insults or claims written on these glandes that have yet to be discovered.

${ }^{147}$ Hallett, "Fulvia, mother of Iullus Antonius," 151. It should be noted that naming Fulvia as the leader of Lucius and Fulvia's forces may have been a method of insulting the soldiers who fought under her. Considering this, we should recognize that Fulvia's role may have been been overstated in the ancient sources in attempts to defame and delegitimize her followers and their cause.

148 These coins were minted by moneyer C. Numonius Vaala in the same year in Rome and Lugdunum (Lyon). Tracene Harvey, "The Visual Representation of Livia on Coins of the Roman Empire" (PhD diss., University of Alberta, 2011), 107.
} 
mints of these coins, slight variations on how they displayed Fulvia as the goddess of victory. ${ }^{149}$ Depicting Fulvia so clearly as the embodiment of 'victory' could suggest that she had a symbolic position in the minds of the soldiers, and possibly others. It has been theorized that perhaps Antony commissioned the coins in order to legitimize Fulvia's authority in managing Antony's political affairs while he was in the East. ${ }^{150}$ They may have also been minted as tokens of Antony's love and affection for his wife, or reminders that Antony had "Victory" on his side, or perhaps as symbols of the homes and families for which Antony's soldiers fought. Likely, they were minted for several of these reasons.

Another interesting note on these coins concerns the duration of their minting. They were made and distributed from 43 BCE to 40 BCE, years which include the events leading up to and throughout the Perusine War. This naturally raises important questions about the implications of these coins being minted during the Perusine War. Whether Antony still had control over the production of these coins during this time is unclear, however, being located in the East far away from the mints in Rome during this time suggests that he was not directly overseeing their creation. We have no record of him attempting to stop the production from afar though. This leaves us with a few possibilities. Perhaps the minters of the coins supported Fulvia and Lucius. Perhaps Fulvia or one of her allies adopted the management of the coin production. Or perhaps Antony, believing it to be in his best interest to remain neutral, simply ignored the creation of this coinage until the defeat of his wife and brother was certain. Antony's intentions, like many of the questions posed throughout this paper, are unlikely to ever have concrete or conclusive answers. However, it remains beneficial to question their multiplicity of possibilities, including the likelihood of more than one intent, motive, or reason.

\footnotetext{
${ }^{149}$ Harvey, "The Visual Representation of Livia," 81.

${ }^{150}$ Harvey, "The Visual Representation of Livia," 111-2.
} 
These coins and sling bullets offer another vital clue to our understanding of Fulvia in their confirmation of her involvement in the Perusine War and the presence of a contemporary 'anti-Fulvia' discourse. The poem by Martial and Cicero's comments on Fulvia support the existence of an contemporary opposition to Fulvia as well, though, perhaps less strongly. The ability to confirm opposition to Fulvia in her lifetime is important because it serves as the strongest evidence we have supporting Fulvia's political actions and influence. If our only evidence for Fulvia's life and actions came from scholars writing hundreds of years after her death, it would be difficult to say definitively whether Fulvia wielded power or influence. We would be left with the only viable option of study being examinations of how Fulvia was perceived. However, the extant, contemporary sources and archaeological finds provide enough evidence to conclude that Fulvia acted politically, the public viewed her as a leader, and she held some symbolic value to her troops. Fulvia was not a scapegoat used by later ancient historians to convey a moral or save the dignity of the men around her, she influenced politics, led troops, and angered her contemporaries enough to provoke an active, anti-Fulvia discourse.

Despite Fulvia's best intentions, and likely to the great joy of these contemporary opponents, Octavian and his forces starved Lucius and his troops into surrender in the early months of 41 BCE. According to Appian, Fulvia fled with her children from Gaul to Dicaearchia with 3,000 cavalry as an escort. From there she travelled to Brundisium, where she boarded a warship that delivered her to Athens. ${ }^{151}$ Our sources make no more mention of Fulvia's children during her escape, though it seems a fair assumption to guess that they continued with her to Greece. On his return from the East that spring, Antony met up with Fulvia at Athens, where it is said he first learned of the conflict and the actions of his wife and brother. He travelled with

${ }^{151}$ App. BC 5.6. 50. 
Fulvia until Sicyon, where she fell ill. ${ }^{152}$ Several of our sources report that Antony refused to see her before he left to return to Italy, an act that they believe disheartened her so thoroughly she lost the will to live and soon expired. ${ }^{153}$

Death was arguably not the end for Fulvia. She lived on in the memories of her children and the hearts of her supporters. She lived on in speeches of her rivals and the histories written by later men. She may have also lived on in memory of Augustus, influencing his actions and policies, possibly without him even knowing it. ${ }^{154}$ And she lives on in this paper, hopefully breathing in new life as we examine her as a more complex and compelling person than the villainous caricature of our histories.

\footnotetext{
${ }^{152}$ App. BC 5.6.55.

153 Bauman, Women and Politics in Ancient Rome, 88; App. BC 5.6.55-59, 5.6.62; Dio 48.28.3.

${ }^{154}$ Hallett, "Fulvia, mother of Iullus Antonius," offers this fascinating argument of Fulvia's legacy and the life of her youngest child, Iullus Antonius.
} 


\section{Conclusion}

Throughout this work I have endeavored to illustrate why Fulvia should be viewed as neither a hero nor a villain. She remains an unprecedented and unconventional Roman woman who achieved a level of political authority unheard of for women of her time. But she was also an ambitious woman who pierced the tongue of her biggest critic and started a civil war likely for not entirely selfless reasons. In order to understand Fulvia as best we can, we have to consider her outside of the judgments of good and evil. Comprehending Fulvia's actions and her motives requires us to transcend moral judgments.

Like Champlin with Nero, I make no attempt to justify her actions or rehabilitate her character. However, while using Champlin's model, it is important to acknowledge that while Fulvia may have had clear, logical motives - whether those are different than the ones our sources assign or not - behind many of her actions, that does not mean that all them did or should. Fulvia was human. She should be allowed to make irrational or illogical decisions based on emotions just like the rest of us. She should be allowed to love, rage, weep, and react irrationally, as we all do. The main issue with Champlin's methodology is its reliance on "rational" motivation. Rationality can be subjective. Additionally, no person, historical or modern, ever functions solely on logical decision-making. This is not to argue that Fulvia's actions were largely motivated by irrational emotions, throughout this work I have endeavored to show how this is not the case. Fulvia calculated and carefully weighed many of her decisions. Rather, I suggest that viewing Fulvia as a wholly rational or irrational actor is flawed. At various points, she was both. 


\section{Bibliography}

Appianus. Civil Wars. Translated by J. L. Strachan-Davidson. Oxford: Oxford University Press, 1951. (App, BC)

Cicero, Marcus Tullius. Philippics. Translated by Walter C. A. Ker. Cambridge: Harvard University Press, 1926. (Cic. Phil.)

Dio, Cassius. Roman History. Translated by Earnest Cary. Cambridge: Harvard University Press, 1989. (Dio)

Martial, Epigrams. Translated by Hallett in "Fulvia, mother of Iullus Antonius: new approaches to the sources on Julia's adultery at Rome.” Helios 33, no. 2 (2006).

Maximus, Valerius. Memorable Deeds and Sayings. Translated by Henry J. Walker. Indianapolis: Hackett Publishing, 2004. (Val. Max.)

Nepos, Cornelius. The Life of Atticus. Translated by Nicholas Horsfall. Oxford: Clarendon Press, 1989. (Nep. Att.)

Paterculus, Velleius. Compendium of Roman History. Translated by Frederick W. Shipley. London: G. P. Putnam's Sons, 1924. (Vell. Pat.)

Plutarch. Plutarchs Lives: Antony. Translated by Bernadotte Perrin. Cambridge: Harvard University Press, 1969. (Plut. Ant.)

Quintilian. The Orator's Education. Translated by Donald A. Russell. Cambridge: Harvard University Press, 2001. (Quint.)

Suetonius. Lives of the Caesars: Augustus. Translated by Catharine Edwards. Oxford: Oxford University Press, 2008. (Suet. Aug.) 
Secondary Materials:

Arkenberg, Jerome S. “Licinii Murenae, Terentii Varrones, and Varrones Murenae: A

Prosopographical Study of Three Roman Families." Historia: Zeitschrift für Alte Geschichte 42, no. 3 (1993): 326-351.

Babcock, Charles L. "The Early Career of Fulvia." The American Journal of Philology 86, no. 1 (1965): 1-32.

Balsdon, J. P. V. D. Roman Women: Their History and Habits. London: Bodley Head, 1962.

Baroin, Catherine. "Remembering one's Ancestors, Following in their Footsteps, being like them: The Role and Forms of Family Memory in the Building of Identity." In Children, Memory, and Family Identity in Roman Culture, edited by Véronique Dasen and Thomas Späth, 19-48. Oxford: Oxford University Press, 2010.

Bauman, Richard A. Women and Politics in Ancient Rome. London: Taylor and Francis, 1994.

Brennan, T. Corey. "Perceptions of Women's Power in the Late Republic." A Companion to Women in the Ancient World, 2012, 354-66.

Boissier, Gaston. Cicero and His Friends: A Study of Roman Society in the Time of Caesar. London: Ward, Lock, and Co., 1970.

Caldwell, Lauren. Roman Girlhood and the Fashioning of Femininity. Cambridge: Cambridge University Press, 2014.

Champlin, Edward. Nero. Cambridge: Harvard University Press, 2003. 
Delia, Diana. "Fulvia Reconsidered." In Women's History and Ancient History, edited by Sarah B. Pomeroy, 197-217. Chapel Hill: University of North Carolina Press, 1991.

DePauw, Linda Grant. Battle Cries and Lullabies: Women in War from Prehistory to the Present. Norman: University of Oklahoma Press, 2000.

Frier, Bruce W. "Natural Fertility and Family Limitation in Roman Marriage." Classical Philology 89, no. 4 (1994): 318-33.

Hallett, Judith P. "Fulvia, mother of Iullus Antonius: new approaches to the sources on Julia's adultery at Rome." Helios 33, no. 2 (2006): 149-64.

Hallett, Judith P. "Perusine Glandes and the Changing Image of Augustus." AJAH 2, no 2 (1977): 151-71.

Hammar, Isak. "Making Enemies: the Logic of Immorality in Ciceronian Oratory." PhD diss., Lund University, 2013.

Harvey, Tracene. "The Visual Representation of Livia on Coins of the Roman Empire." PhD diss., University of Alberta, 2011.

Hersh, Karen K. The Roman Wedding: Ritual and Meaning in Antiquity. Cambridge: Cambridge University Press, 2010.

Korfmann, Manfred. "The Sling as a Weapon.” The Scientific American, 229, no 34 (1973): 3549.

Lindsay, H. "The Biography of Atticus: Cornelius Nepos on the Philosophical and Ethical Background of Pomponius Atticus." Latomus, 57, no. 2, (1998): 324-336. 
Ma, John. "A Note on Lead Projectiles (Glandes, Molybdides) in Support of Sling Bullets: a Reply to T. Rihll." Journal of Roman Archaeology 23 (2010): 427-28.

Phang, Sara Elise. "Military Documents, Language, and Literacy." In A Companion to the Roman Army, edited by Paul Erdkamp, 286-305. Sussex, Wiley-Blackwell Publishing, 2007.

Pomeroy, Sarah B. Goddesses, Whores, Wives, and Slaves. New York: Schocken Books, 1995.

Rawson, Beryl. "The Roman Family." In The Family in Ancient Rome: New Perspectives, edited by Beryl Rawson, 1-57. New York: Cornell University Press, 1986.

Salisbury, Joyce. Encyclopedia of Women in the Ancient World. Santa Barbara: ABC-CLIO, 2001.

Smith, William Anton. Ancient Education. New York: Philosophical Library, 1955.

Syme, Ronald. The Roman Revolution. Oxford: Oxford University Press, 2002.

Talbert, Richard J. A. and Fred S. Naiden. Mercury's Wings: Exploring Modes of Communication in the Ancient World. Oxford: Oxford University Press, 2017.

Tatum, W. Jeffrey. The Patrician Tribune: Publius Clodius Pulcher. Chapel Hill: University of North Carolina Press, 2017.

Weigall, Arthur. The Life and Times of Marc Antony. New York: G.P. Putnam's Sons, 1931.

Weir, Allison. “A Study of Fulvia.” MA Thesis, Queen’s University, 2007.

Welch, Kathryn E. "Antony, Fulvia, and the Ghost of Clodius in 47 B. C." Greece \& Rome 42, no. 2 (1995): 182-201. 